\title{
Biomass derived tar decomposition over coal char bed
}

\author{
Supachita Krerkkaiwan $^{\mathrm{a}}$, Atsushi Tsutsumi ${ }^{\mathrm{c}}$, Prapan Kuchonthara ${ }^{\mathrm{a}, \mathrm{b}, *}$ \\ ${ }^{a}$ Department of Chemical Technology, Faculty of Science, Chulalongkorn University, \\ Bangkok 10330 Thailand \\ b National Centre of Excellence for Petroleum, Petrochemicals and Advanced Materials, \\ Chulalongkorn University, Bangkok 10330 Thailand \\ c Collaborative Research Centre for Energy Engineering (CEE), Institute of Industrial Science, \\ the University of Tokyo, Tokyo 153-8505, Japan
}

${ }^{*}$ Corresponding author, e-mail: prapan.k@chula.ac.th

Received 28 Feb 2013

Accepted 30 May 2013

\begin{abstract}
The effect of coal char on the decomposition of rice straw derived tar was investigated in a two-stage fixed bed reactor. The reactor was divided into a pyrolysis zone (upper part) and a volatile-char contacting zone (lower part). Rice straw was pyrolysed at different temperatures in the upper part. Coal char, prepared by the pyrolysis of Indonesian coal at either $600^{\circ} \mathrm{C}$ (char600) or $800{ }^{\circ} \mathrm{C}$ (char800), was located in the lower part. Volatiles from the rice straw (upper part) were produced and then came in contact with the coal char at the lower part under the $\mathrm{N}_{2}$ (pyrolysis) or steam/ $\mathrm{N}_{2}$ (steam reforming) gas flow. Under pyrolysis, both char600 and char800 exhibited a catalytic effect on the thermal tar decomposition. The coal chars also played a significant catalytic activity on the decomposition of the heavy aromatic hydrocarbons that were generated at a high pyrolysis temperature. In the presence of steam, char600 also exhibited a catalytic role in tar steam reforming, while char800 did not reveal any such significant catalytic activity because of the predominant coke/carbon formation.
\end{abstract}

KEYWORDS: tar reduction, pyrolysis, gasification, char catalyst

\section{INTRODUCTION}

Gasification is an effective technology for converting hydrocarbon-based materials into gaseous fuels, called 'synthesis gas' that is mainly composed of hydrogen $\left(\mathrm{H}_{2}\right)$ and carbon monoxide $(\mathrm{CO})$. The produced gas can be applied for power generation, petrochemical production of methanol and dimethylether, and/or in the Fischer-Tropsch process to produce synthetic oil. Synthesis gas is produced together with various by-products such as oxides of nitrogen $\left(\mathrm{NO}_{x}\right)$ and sulphur $\left(\mathrm{SO}_{x}\right)$, tar, and particulates. Tar can condense when the temperature is lower than its dew point and plug or foul the pipeline and gasifier and so decrease the overall process efficiency ${ }^{1}$. Consequently, tar elimination is an important preceding step for cleaning the gas product. Catalytic tar elimination is one potential method for tar reduction. Anis et $\mathrm{al}^{2}$ classified effective catalysts for tar reduction into the six groups of (i) nickel-based, (ii) non-nickel metal, (iii) alkali metal, (iv) basic, (v) acid and (vi) activated carbon catalysts. Recently, char derived from the pyrolysis of coal or biomass, called 'pyrolysed-char', has been reported as a catalyst for tar elimination. One of its key advantages is that char production and tar reduction can be implemented simultaneously inside the gasifier by controlling the parameters and configurations $^{3}$. The tar reforming ability of char is influenced by its surface area and the inherent mineral content (in particular $\mathrm{Na}, \mathrm{K}, \mathrm{Ca}$, and $\mathrm{Mg}$ ) on the char surface ${ }^{4}$. In previous studies, char catalyst was mostly obtained from the pyrolysis of biomass sources because of its high porosity and high surface minerals content $^{5-7}$. However, the yield of char obtained from the pyrolysis of biomass was relatively low compared with that of coal char due to the lower fixed carbon level in biomass. A few studies have addressed the catalytic activity of coal char prepared from the pyrolysis of low-rank coal, such as Brown coal ${ }^{4,8}$ and lignite ${ }^{3}$. Nevertheless, those studies focused on the reduction of coal derived tar and so the current understanding of the catalytic effect of coal char on biomass derived tar is still inadequate. In addition, the co-pyrolysis/gasification of coal char and biomass has recently gained in interest due to the synergetic effect, in terms of the product yield, gas composition and the overall process efficiency ${ }^{9-11}$. A more complete knowledge of the coal char and biomass tar interactions is expected to facilitate the optimal design and operation of processes involving the co- 
Table 1 Proximate and ultimate analyses of rice straw, Indonesian coal and coal char samples.

\begin{tabular}{|c|c|c|c|c|c|c|}
\hline \multirow[t]{2}{*}{ Sample } & \multicolumn{6}{|c|}{ Proximate analysis (wt\%) } \\
\hline & Moisture & \multicolumn{2}{|c|}{ Ash } & \multicolumn{2}{|c|}{ Volatile matter } & Fixed Carbon \\
\hline Rice straw & 6.43 & \multicolumn{2}{|c|}{11.22} & \multicolumn{2}{|c|}{61.95} & 29.25 \\
\hline Coal & 12.41 & \multicolumn{2}{|c|}{8.39} & \multicolumn{2}{|c|}{36.84} & 42.36 \\
\hline Char600 & 4.70 & \multicolumn{2}{|c|}{27.16} & \multicolumn{2}{|c|}{5.64} & 62.50 \\
\hline \multirow[t]{3}{*}{ Char800 } & 6.95 & \multicolumn{2}{|c|}{33.18} & \multicolumn{2}{|c|}{5.07} & 54.80 \\
\hline & \multicolumn{5}{|c|}{ Ultimate analysis (wt\% dry ash-free basis) } & $\mathrm{H} / \mathrm{C}$ molar \\
\hline & $\mathrm{C}$ & $\mathrm{H}$ & $\mathrm{N}$ & $S^{a}$ & $\mathrm{O}$ (diff.) & ratio \\
\hline Rice straw & 45.30 & 6.93 & 0.92 & 0.14 & 46.71 & 1.84 \\
\hline Coal & 72.13 & 6.67 & 1.40 & 0.22 & 19.58 & 1.11 \\
\hline Char600 & 94.13 & 2.39 & 1.45 & n.d. ${ }^{b}$ & $2.02^{\mathrm{c}}$ & 0.30 \\
\hline Char800 & 91.38 & 1.83 & 0.90 & n.d. & $5.89^{c}$ & 0.24 \\
\hline
\end{tabular}

pyrolysis/gasification of coal and biomass. Furthermore, the catalytic decomposition of biomass derived tar is related to its composition, and the composition and structure of tar have been reported to significantly depend on the pyrolysis temperature ${ }^{12,13}$.

In this study, the catalytic effect of coal char on biomass derived tar reduction under both thermal decomposition and steam reforming was investigated, using a two-stage fixed bed reactor. The influences of coal char preparing temperature and biomass pyrolysis temperature were explored. In addition, the prepared coal chars were characterized by BrunauerEmmitt-Teller (BET), scanning electron microscopy (SEM) and X-ray fluorescence microscopy (XRF), while the product tar composition was analysed by gas chromatography-mass spectroscopy (GC-MS).

\section{MATERIALS AND METHODS}

\section{Materials}

Rice straw and Indonesian subbituminous coal was used as the biomass and original coal samples, respectively. All of the samples were ground and sieved to select particles in the size range of $150-250 \mu \mathrm{m}$. To remove the effect of moisture content and variations between samples, the samples were oven-dried at $110^{\circ} \mathrm{C}$ for $1 \mathrm{~h}$ and then stored in a desiccator before use. Proximate and ultimate analyses of the samples were presented in Table 1.

\section{Coal char preparation}

Coal chars were prepared in a conventional fixed bed reactor, using $7 \mathrm{~g}$ of Indonesian coal that was placed inside the quartz reactor $(19 \mathrm{~mm}$ ID and $40 \mathrm{~cm}$ long heating zone). The coal was slowly pyrolysed under a nitrogen $\left(\mathrm{N}_{2}\right)$ flow rate of $120 \mathrm{ml} / \mathrm{min}$ as the temperature was increased from room temperature to the desired temperature and then held for $60 \mathrm{~min}$. Two types of coal char were prepared by performing the pyrolysis at either 600 or $800^{\circ} \mathrm{C}$ and hereafter are called 'char600' and 'char800', respectively. The mineral contents in each coal char was characterized by XRF using a Phillips model PW2400 instrument. In addition, the specific surface area, pore volume and pore size of the coal chars were measured by $\mathrm{N}_{2}$ adsorption at $-196{ }^{\circ} \mathrm{C}$ on a model Quantachrome (Autosorb-1) instrument and degassing the sample before adsorption at $300{ }^{\circ} \mathrm{C}$ for $6 \mathrm{~h}$. The data were then subjected to analysis using the BET method. In addition, the morphology of each coal char sample was characterized by SEM method, using a JEOL model JSM-5410LV.

\section{Pyrolysis and steam gasification in a two-stage fixed bed reactor}

Pyrolysis and steam gasification of rice straw were carried out in a two-stage fixed bed reactor, schematically illustrated in Fig. 1. The reactor consisted of an inner quartz tube of $9 \mathrm{~mm}$ ID and $60 \mathrm{~cm}$ length, placed inside the outer quartz tube of $19 \mathrm{~mm}$ ID and $89 \mathrm{~cm}$ length. The reactor was divided into two parts; an upper part where biomass pyrolysis took place (pyrolysis zone) and a lower part where the coal char was located and made contact with the rice straw volatiles from the pyrolysis zone (volatile-char contacting zone). The reaction temperature of the upper and lower zone was separately controlled by an 


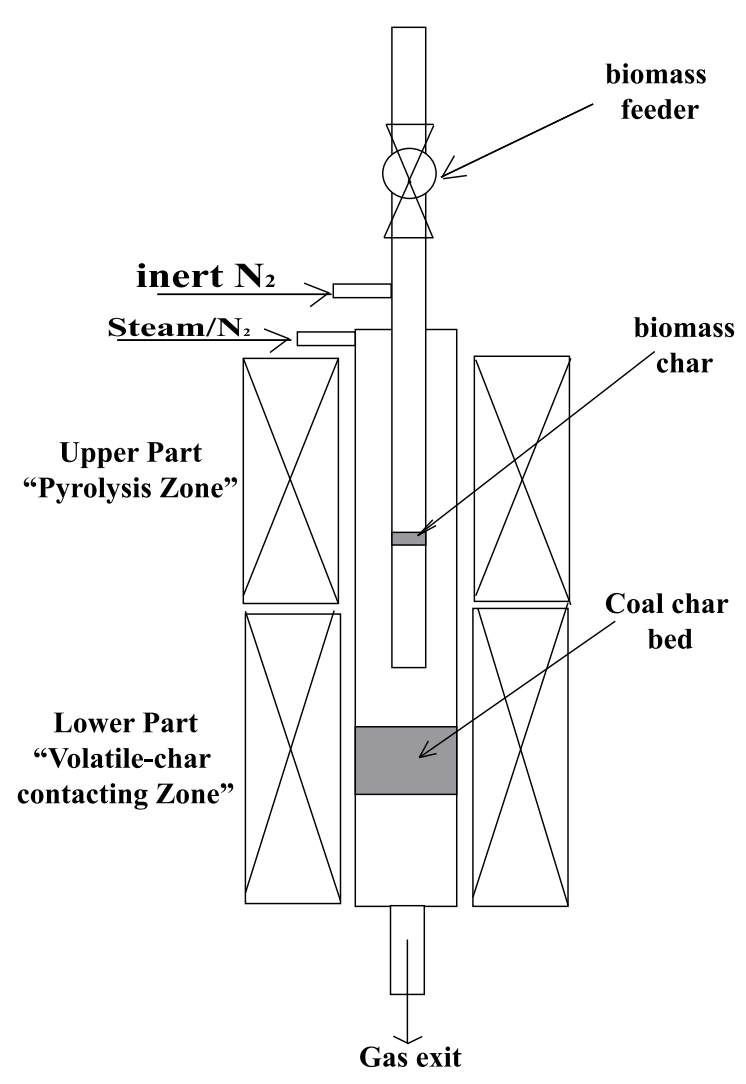

Fig. 1 Schematic diagram of a two-stage fixed bed reactor.

external Carbolite model MTP 12 and Lenton model LTF 12 electric furnace, respectively.

First, $50 \mathrm{mg}$ of coal char or inert bed (inactive alumina) with a bed height of $2 \mathrm{~cm}$ was placed in the lower part. $\mathrm{N}_{2}$ was used as the carrier gas with flow rates of 80 and $30 \mathrm{ml} / \mathrm{min}$ in the inner tube and outer tube, respectively. After purging for $60 \mathrm{~min}$, both electric furnaces were heated up to their respective desired temperature and then $120 \mathrm{mg}$ of rice straw was dropped into the pyrolysis zone in the inner tube. The rice straw pyrolysed-char was located over the filter in the inner tube, only rice straw derived volatiles (including tar and gas) passed through the filter and came in contact with the coal char in the lower volatile-char contacting zone. An $\mathrm{N}_{2}$ gas flow was used for the pyrolysis while $60 \%(\mathrm{v} / \mathrm{v})$ steam and $\mathrm{N}_{2}$ mixture was introduced for the steam gasification condition. Some of the heavy tars were condensed by an iced-tar trap filled with isopropanol and round glass beads of $6 \mathrm{~mm}$ in diameter for recovering condensable compounds. Gaseous products were collected in a 2-1 gas bag, changed every 15 min after the sample was dropped, for further quantitative analysis. The reaction was performed for $1 \mathrm{~h}$.

In addition, the solid residuals of rice straw in the inner tube were collected and then weighted for calculation of char yield. Tar yield (wt $\%$ of rice straw feed) was determined as

$$
\text { Tar yield }=100-Y_{\text {gas }}-Y_{\text {char }},
$$

where $Y_{\text {gas }}$ and $Y_{\text {char }}$ represent the gas yield and char yield based on $100 \mathrm{~g}$ of rice straw feed, respectively. For this situation, tar yield might include soot or coke which was possible formed over the coal char surfaces during the reaction.

\section{Characterization of the products}

The produced gases, which mainly consisted of $\mathrm{H}_{2}$, $\mathrm{CO}$, methane $\left(\mathrm{CH}_{4}\right)$ and $\mathrm{CO}_{2}$, was quantitatively analysed by GC (Shimadzu GC-2014) with a thermal conductivity detector using a Unibeads $\mathrm{C}$ column (3.00 $\mathrm{mm} \mathrm{ID} \times 200 \mathrm{~cm}$ length). To determine the chemical composition of the condensed tar in the icetar trap, it was analysed by GC-MS using a Varian Model Saturn 2200 instrument equipped with a DB$5 \mathrm{~ms}$ capillary column (J \& W Scientific) of $0.25 \mathrm{~mm}$ OD $\times 0.25 \mathrm{~mm}$ film thickness $\times 30 \mathrm{~m}$ length, with helium as the carrier gas. The molecular weight scan range was $50-650 \mathrm{~m} / \mathrm{z}$ with a $5 \mathrm{~min}$ solvent cut time. The column was held at $50{ }^{\circ} \mathrm{C}$ for $3 \mathrm{~min}$, and then the temperature was increased to $220^{\circ} \mathrm{C}$ at rate of $20^{\circ} \mathrm{C} / \mathrm{min}$ and held for $40 \mathrm{~min}$.

\section{RESULTS AND DISCUSSION}

\section{Characterization of prepared coal chars}

From the proximate and ultimate analyses (Table 1), it was found that both char600 and char800 had lower moisture, volatile matter, $\mathrm{H} / \mathrm{C}$ molar ratio, and oxygen contents, but higher ash and fixed carbon contents compared to the original coal. This was due to the release of volatile matter during the slow pyrolysis of coal at the high applied temperature $\left(600\right.$ or $\left.800{ }^{\circ} \mathrm{C}\right)$ resulting in the char formation via the secondary reactions such as polymerization and thermal cracking of the heavier volatile products ${ }^{14}$. Comparing the two coal chars, char800 had a lower H/C molar ratio because the char naturally becomes more carbonaceous in structure at higher temperature. Table 2 shows the BET surface area, pore volume and average pore size of the two prepared coal chars. The BET surface area and pore volume of char600 were 4.1- and 2.8-fold, respectively, higher than those of char800. On the other hand, the average pore size of char600 was 1.4fold lower than that of char800. This is attributed to the destruction of the carbon matrix in char800 at 
Table 2 BET surface area, pore volume and pore size of the prepared coal char.

\begin{tabular}{lcc}
\hline Coal char sample & Char600 & Char800 \\
\hline BET surface area $\left(\mathrm{m}^{2} / \mathrm{g}\right)$ & 200.71 & 48.92 \\
Pore volume $\left(\mathrm{cm}^{3} / \mathrm{g}\right)$ & 0.1389 & 0.0487 \\
Average pore size $(\AA)$ & 27.68 & 39.85 \\
\hline
\end{tabular}
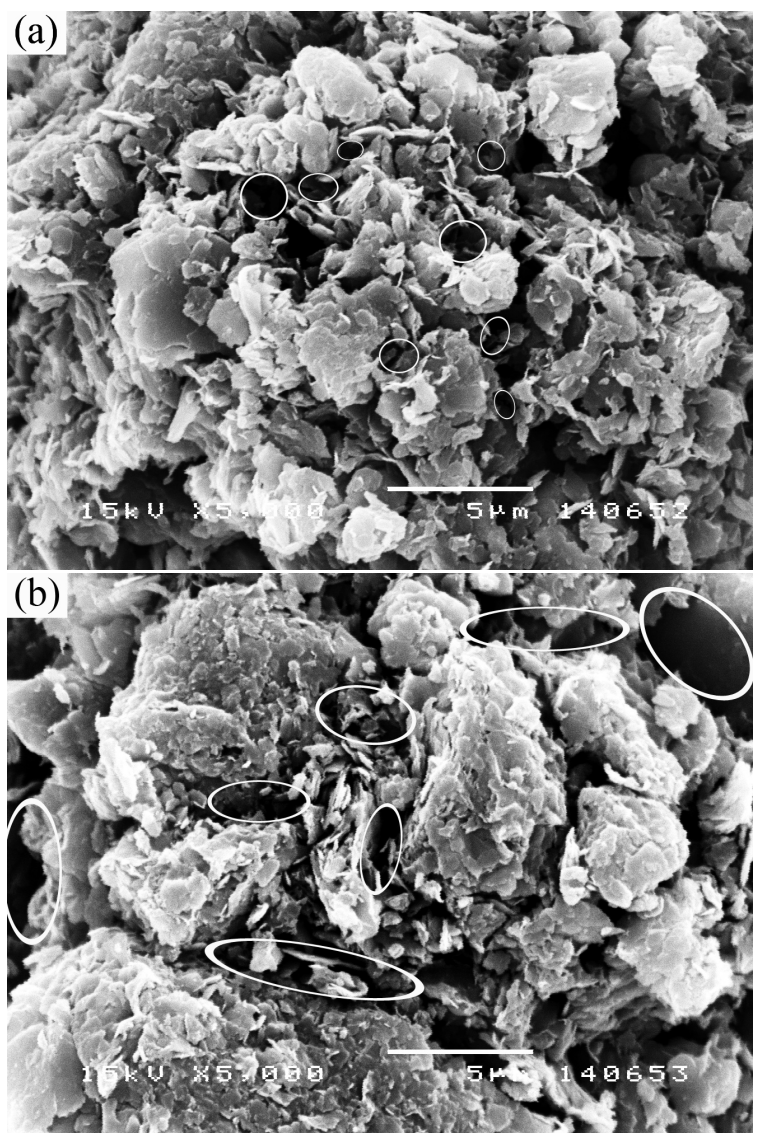

Fig. 2 SEM images of coal char (a) char600 and (b) char800.

the higher temperature, resulting in the formation of a larger pore diameter ${ }^{15}$.

The BET result was supported by the SEM analysis which the surface of char800 was seen to be occupied by a dense carbon matrix with larger pores (Fig. 2). In contrast, the char600 surface looked like loosely-packed carbon with smaller pores. This result agrees with previous studies have reported that, at high thermal treatment temperatures, the crystalline carbon structure increased and was accompanied by the decrease of micropores and the increase of macropores ${ }^{16-19}$. The mineral contents of coal char, especially alkali alkaline earth metallic (AAEM) species,
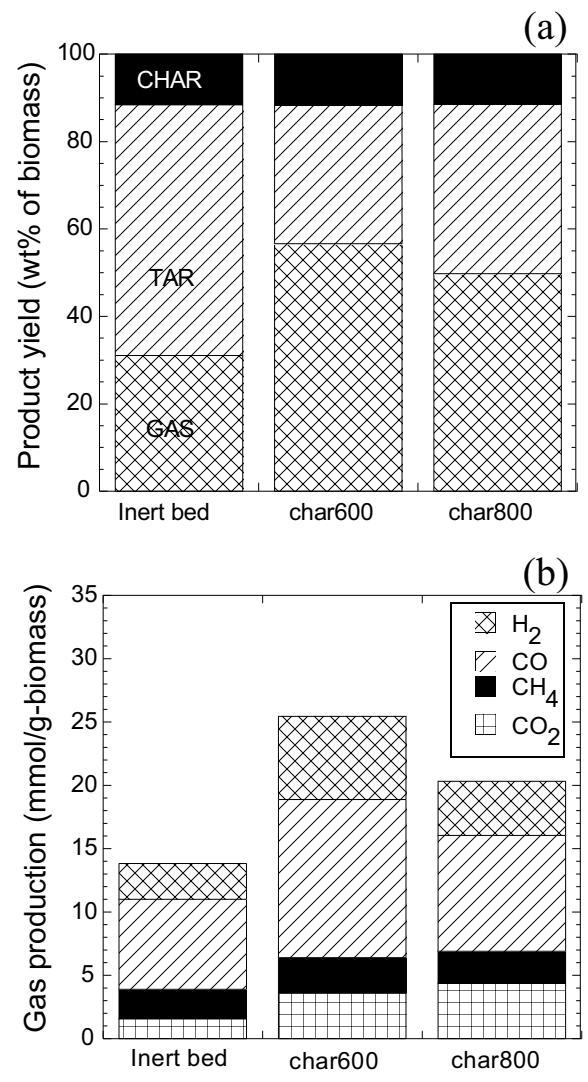

Fig. 3 Effect of coal char on (a) product yield and (b) gas production from the pyrolysis of rice straw at $800^{\circ} \mathrm{C}$.

have been reported to be the key catalyst species for tar decomposition and for char steam gasification ${ }^{20,21}$. The AAEM content of the prepared coal chars was characterized by XRF which revealed that char600 had lower AAEM and $\mathrm{Si}$ contents than char800 (Table 3). However, the catalytic activity of coal char not only depended on the presenting of AAEM species but also significantly relied on char structure, as discussed later.

\section{Effect of coal char on rice straw pyrolysis}

The effect of coal char on product yield of rice straw pyrolysis at $800^{\circ} \mathrm{C}$ is shown in Fig. 3. Note that the amount of gas produced from coal char was subtracted from the total amount of detected gas. In this section, the temperature at the upper and lower part of the twostage fixed bed reactor was $800^{\circ} \mathrm{C}$. When inactive alumina was used (inert bed), the pyrolysis of rice straw proceeded via the primary thermal decomposition to tar as the main product of $60 \mathrm{wt} \%$, with about 10 and $30 \mathrm{wt} \%$ char and gas products, respectively. In the presence of char600 and char800, the tar yield 
Table 3 AAEM and Si contents over coal char surfaces by XRF technique.

\begin{tabular}{lccccr}
\hline Sample & \multicolumn{3}{c}{ Element content (wt\%) } \\
\cline { 2 - 6 } & $\mathrm{Na}$ & $\mathrm{K}$ & $\mathrm{Mg}$ & $\mathrm{Ca}$ & $\mathrm{Si}$ \\
\hline Fresh coal char & & & & \\
Char600 & 0.082 & 0.373 & 0.169 & 2.207 & 3.422 \\
Char800 & 0.096 & 0.547 & 0.236 & 3.200 & 4.035 \\
After used coal char & & & & \\
Pyrolysis at $800{ }^{\circ} \mathrm{C}$ & & & & \\
Char600 & 0.045 & 0.523 & 0.235 & 1.543 & 7.700 \\
Char800 & 0.030 & 0.365 & 0.187 & & 5.293 \\
Gasification at $800^{\circ} \mathrm{C}$ & & & & \\
Char600 & 0.022 & 0.191 & 0.175 & 1.543 & 2.988 \\
Char800 & 0.015 & 0.266 & 0.133 & 1.186 & 3.161 \\
\hline
\end{tabular}

decreased from 60 to 35 and $40 \mathrm{wt} \%$, respectively, and the gas yield increased from 30-55 and $50 \mathrm{wt} \%$, respectively. Thus both char600 and char800 coal chars likely play a catalytic role in the decomposition of rice straw derived tar leading to higher gaseous products. This result agrees with those of previous studies $^{3,6}$ that also showed a catalytic role of hot bed charcoal (biomass char) on tar reduction under the pyrolysis of biomass. However, the char600 and char800 coal chars were not equally effective at catalysing the decomposition of rice straw derived tar (in terms of the tar conversion to gaseous products). Rather, compared to char800, char600 gave a higher gas yield with a corresponding lower tar yield. One explanation lies in that char600 had a significantly larger total BET surface area (4.1-fold) and pore volume (2.85-fold) than char800 (Table 2). It has previously been reported that tar reduction over char surfaces followed two steps of tar deposition to form secondary char and/or coke and steam gasification of coke $^{4,22}$. Although no external steam was introduced, the steam gasification presumably could have taken place from the pyrolytic steam that was generated from the biomass pyrolysis ${ }^{23,24}$. Hence, the higher surface area of char600 could promote tar deposition, forming coke that was decomposed consecutively into gaseous products by steam gasification in the following reaction:

$$
\mathrm{C}+\mathrm{H}_{2} \mathrm{O} \rightleftharpoons \mathrm{CO}+\mathrm{H}_{2}
$$

The catalytic steam reforming of soot or coke by alkali metallic species was also reported in the previous coal pyrolysis $^{21}$. An alternative explanation is that the different catalytic behaviour could reflect the difference in the AAEM levels on the surface of the coal chars. The spent char600 after pyrolysis generally had a higher AAEM content than the fresh char600, especially K (1.4-fold, Table 3$)$. Rice straw has a relatively high $\mathrm{K}$ content which can be released in the vapour phase at around $57 \mathrm{wt} \%$ (not shown). So it could be assumed that the increased $\mathrm{K}$ content in the spent char600 might be due to the formation of the phenolate group $(\mathrm{K}-\mathrm{O}-\mathrm{C})$ that bonded between the released $\mathrm{K}$ from rice straw and carbon matrix of coal char $^{25-27}$. The phenolate group has been reported to be a catalytic species for carbon-steam reaction ${ }^{27-30}$. At the same time, the volatilization of AAEM over the coal char surfaces was promoted by the H-radicals which released from the thermal cracking of rice straw derived volatiles, following the reaction:

$$
\mathrm{CM}-\mathrm{M}+\mathrm{H} \rightleftharpoons \mathrm{CM}-\mathrm{H}+\mathrm{M}
$$

where $\mathrm{CM}, \mathrm{M}$, and $\mathrm{H}$ represented the char matrix, AAEMs, and H-radical from the volatile, respectively $^{21}$. According to this, it could be supposed that in the case of char600, the volatilization of AAEM in reaction (3) was a less significant factor than the formation of the phenolate group. On the other hand, the spent char800 had a lower AAEM content, including $\mathrm{K}$ (1.5-fold) than the original unused char800. Wood et $\mathrm{al}^{31}$ reported that the catalytic species including $\mathrm{K}$, undergo a chemical and physical transformation to form a molten $\mathrm{K}_{2} \mathrm{O}$ film that cover the char surfaces. Hence, the char800 probably possessed a lower formation level of the phenolate group because of its lower surface area.

The effect of the two types of coal char on the produced gases $\left(\mathrm{H}_{2}, \mathrm{CO}, \mathrm{CH}_{4}\right.$, and $\left.\mathrm{CO}_{2}\right)$ from rice straw pyrolysis at $800{ }^{\circ} \mathrm{C}$ is shown in Fig. 3b. In the case of the inert bed, rice straw pyrolysis generated $\mathrm{CO}$ as the main component. This might be attributed to the relatively high cellulose content in rice straw $(\sim 32 \mathrm{wt} \%)^{23}$, which contains ether $(\mathrm{C}-\mathrm{O}-\mathrm{C})$, and carbonyl $(\mathrm{C}=\mathrm{O})$ groups that decompose to form 


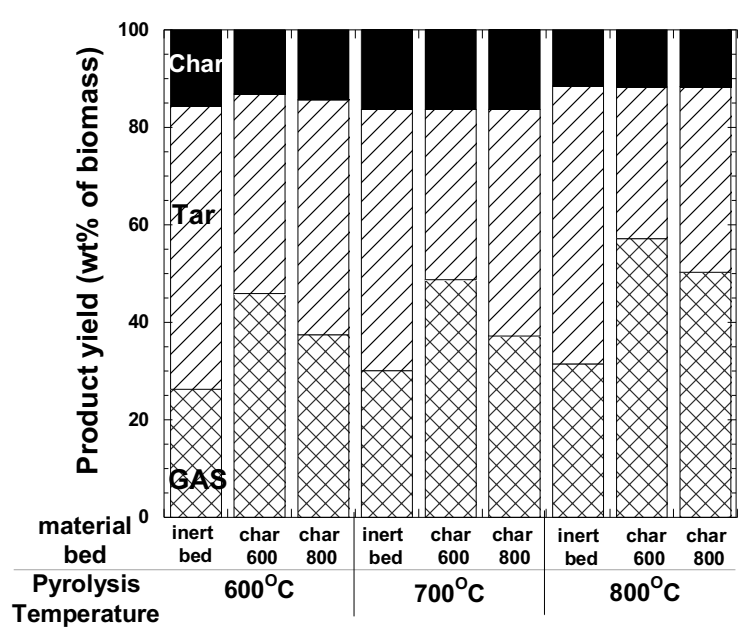

Fig. 4 Effect of pyrolysis temperature on product yield of rice straw pyrolysis with the presence of coal char and inactive alumina.

$\mathrm{CO}^{23,32}$. The presence of char600 resulted in a substantially higher total gas production level (1.9fold more than in the inert bed), due mainly to a higher production level of $\mathrm{H}_{2}, \mathrm{CO}$, and $\mathrm{CO}_{2}$. This increased gas production could be explained as that the carbon steam gasification was promoted by the high active surfaces of char600 accompanied with the catalytic behaviour of the AAEMs on coal char surfaces, as mentioned above. This result showed a good agreement with the previous literature ${ }^{6}$, which reported that the carbon steam gasification (reaction (2)) was an additional reaction involved in tar decomposition in the presence of char. The catalytic effect of char600, in terms of the increased gas products (mainly $\mathrm{H}_{2}$ and $\mathrm{CO}$ ), was found to be more significant than that of char800. This may relate to the lower level of retained AAEMs on the char800 surfaces after the pyrolysis (Table 3).

\section{Effect of pyrolysis temperature on rice straw pyrolysis}

The effect of pyrolysis temperature on tar, char and gas product yield from rice straw pyrolysis with the presence of the coal chars or inactive alumina (inert bed) is shown in Fig. 4. Notice that the temperature of the volatile-char contacting zone (lower part) was maintained at $800^{\circ} \mathrm{C}$ and only the temperature of the pyrolysis zone (upper part) was varied at 600,700 , or $800{ }^{\circ} \mathrm{C}$. It was observed that gas yield dramatically increased while tar yield decreased with the increase of pyrolysis temperature for all three material beds. The catalytic effect of coal char on the reduction of tar,
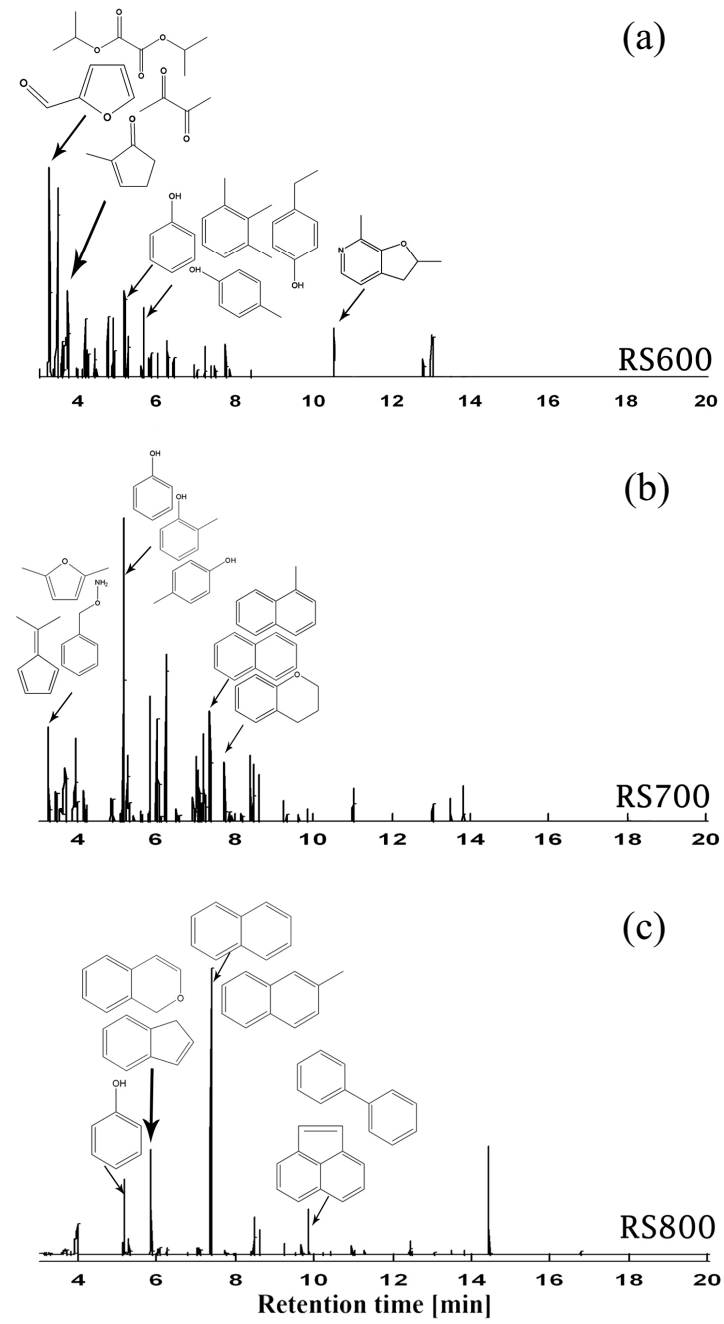

Fig. 5 Effect of pyrolysis temperature on GC-MS patterns of rice straw derived tar at (a) $600{ }^{\circ} \mathrm{C}$, (b) $700^{\circ} \mathrm{C}$ and (c) $800{ }^{\circ} \mathrm{C}$.

compared to that obtained with the inert bed, was more significant as the pyrolysis temperature increased. In addition, the char600 performed more effectively as a catalyst for tar reduction than the char800 at all three pyrolysis temperatures.

The tar derived from rice straw pyrolysis at 600 , 700 , and $800^{\circ} \mathrm{C}$ was characterized by GC-MS. It revealed that the tar derived from the pyrolysis at temperature of $600^{\circ} \mathrm{C}$ mainly consisted of oxygenated compounds (ketones and esters), phenols, and some benzene derivatives (Fig. 5a). These components have previously been reported as the major components of tar derived from cellulose and hemicelluloses decomposition at $600{ }^{\circ} \mathrm{C}$ during rice straw pyrolysis ${ }^{33,34}$. At pyrolysis temperature of $700^{\circ} \mathrm{C}$, the oxygenated com- 
pounds disappeared with an increase in the level of phenolic compounds and some light aromatics, such as benzene and naphthalene (Fig. 5b). Further increasing the pyrolysis temperature to $800{ }^{\circ} \mathrm{C}$ resulted in a decrease in the content of phenols whereas heavy aromatic compounds, such as naphthalene and anthracene became more predominant (Fig. 5c). This result is consistent with that previously reported for the composition of the tar derived from the pyrolysis of pine wood. Tar derived from the pyrolysis of pine wood at $600{ }^{\circ} \mathrm{C}$ contains mostly phenolic compounds while the heavy aromatic compounds, such as anthracene and fluorine, became more dominant at the pyrolysis temperatures above $700{ }^{\circ} \mathrm{C}^{3}$. From the obtained product yields, it appeared that the catalytic activity of the coal char for tar reduction significantly depended on the tar structure that was formed at different pyrolysis temperatures. Heavy aromatic compounds in the tar were preferentially decomposed over the coal chars compared to that for the oxygenated compounds and light hydrocarbons.

Hosokai et $\mathrm{al}^{35}$ also reported that the aromatic compounds, and especially naphthalene, were almost completely decomposed on charcoal.

\section{Effect of coal char on rice straw steam gasification}

The effect of coal char on the product yield from rice straw following steam gasification is shown in Fig. 6a. Note that the product distribution was evaluated and reported in terms of the carbon balance of the rice straw, and so the gas products generated from the steam gasification of the coal char were completely removed. The presence of char600 gave the lowest carbon conversion into tar $(\sim 20 \mathrm{wt} \%)$. The highest carbon conversion into gas $(\sim 83 \mathrm{wt} \%)$ at some 1.34 and 4.15-fold higher than with the inert bed and char800, respectively. It indicates that the catalytic effect of char600 also occurs in the rice straw steam gasification but is more significant than that in the rice straw pyrolysis. This is probably due to tar steam reforming promoted by the external steam. Min et $\mathrm{al}^{36}$ reported that the role of external steam for the reforming of volatile involved two completive reactions. First is the direct steam reforming to convert volatile into the small gaseous molecules. The second is the deposition of tar to generated coke and subsequently the gasification of coke to produce gas product. With the presence of coal char, the second way was probably more significant. This assumption was also supported by a previous study which reported that the aromatic compound was decomposed over the charcoal (wood char) by coking rather than the direct steam reforming ${ }^{35}$. In the case of char600,
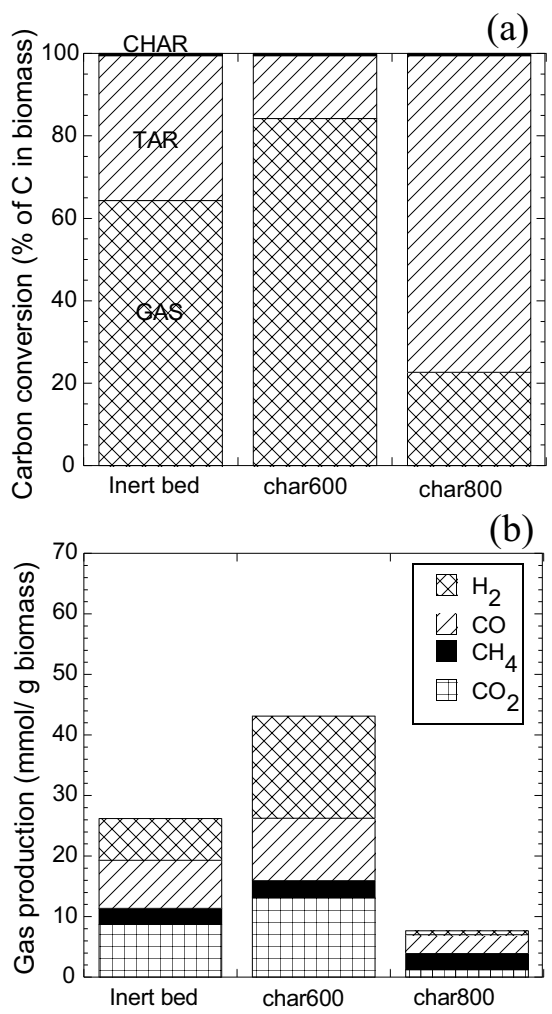

Fig. 6 Effect of coal char on (a) carbon conversion and (b) gas production from the steam gasification of rice straw at $800^{\circ} \mathrm{C}$.

the existence of high surface area and pore volume induced the formation of coke/carbon over the char surfaces. In addition, the presence of external steam and AAEMs on its surfaces was promoted the catalytic coke/carbon steam gasification following reactions (4) $-(7)^{28}$;

$$
\begin{aligned}
\mathrm{M}+\mathrm{H}_{2} \mathrm{O} & \rightleftharpoons \mathrm{M}(\mathrm{O})+\mathrm{H}_{2} \\
\mathrm{M}(\mathrm{O})+\mathrm{C} & \rightleftharpoons \mathrm{C}(\mathrm{O})+\mathrm{M} \\
\mathrm{C}(\mathrm{O}) & \rightleftharpoons \mathrm{CO} \\
\mathrm{C}(\mathrm{O})+\mathrm{M}(\mathrm{O}) & \rightleftharpoons \mathrm{M}+\mathrm{CO}_{2}
\end{aligned}
$$

where $\mathrm{M}, \mathrm{M}(\mathrm{O})$, and $\mathrm{C}(\mathrm{O})$ represent the AAEMs (especially alkali metals), alkali-oxygen bond on the carbon surfaces, and the carbon-oxygen bond on the carbon surfaces, respectively. Hence the char600 showed the significant catalytic activity for tar steam reforming.

In contrast, the presence of char800 gave a higher carbon conversion into $\operatorname{tar}(\sim 75 \mathrm{wt} \%)$ and a lower carbon conversion into gas $(\sim 23 \mathrm{wt} \%)$ than the inactive alumina. This indicates that the formation of coke/carbon is more dominant than the catalytic 
coke gasification on the surfaces of char800. Hosakai et $\mathrm{al}^{35}$ reported that the catalytic activity of coal char could be maintained when the rate of coke gasification was higher than the rate of coke formation. The rate of coke steam gasification could be enhanced by the existence of AAEM remaining on char surfaces, in particular $\mathrm{K}^{30,37}$ and $\mathrm{Ca}^{20}$. As mentioned above, the formation of phenolated group $(\mathrm{K}-\mathrm{O}-\mathrm{C})$ between the volatile $\mathrm{K}$ from rice straw and coal char surfaces could be preferably formed over the char600 surfaces rather than char800 surfaces. Hence the catalytic effect of $\mathrm{K}$ for coke/carbon steam gasification in cases of char800 could be less dominant. In addition, the contents of $\mathrm{Ca}$ on the spent char800 surfaces after gasification were essentially decreased compared to the original char $(63 \%$ reduction see Table 3$)$. It could be supposed that the steam gasification of coke which is deposited on the char800 surfaces was more decomposed than that of the char600 due to the less catalytic activity of the AAEMs. This resulted in the largely decrease of carbon conversion into gas, as evidenced in Fig. 6 a.

The effect of coal char on the production level of the four principal types of gas from rice straw steam gasification at $800^{\circ} \mathrm{C}$ is shown in Fig. 6b. Char600 gave a higher net level and proportion of $\mathrm{H}_{2}$ and $\mathrm{CO}_{2}$ and a slightly lower net level and proportion of $\mathrm{CO}$ than with the inert bed. Presumably, the catalytic effect of char600 promoted tar steam reforming and the water gas shift reaction ${ }^{21}$. In contrast, the net and proportional level of all gas production significantly decreased in the presence of char800 compared to that in the inert bed.

\section{CONCLUSIONS}

The catalytic activity of coal char on the pyrolytic decomposition of rice straw derived tar was higher with coal char that had been prepared at a lower pyrolysis temperature (char600) compared to that prepared at a higher pyrolysis temperature (char800). This is likely to be due to the higher total surface, pore volume and the content of catalytic AAEM species over the char600 surfaces. The catalytic role of coal char preferentially played on the decomposition of heavy aromatic hydrocarbons that were generated at a high pyrolysis temperature $\left(800^{\circ} \mathrm{C}\right)$. Moreover, in steam gasification, only char600 and not char800 showed any catalytic role for tar steam reforming, leading to an increase in the $\mathrm{H}_{2}, \mathrm{CO}$, and $\mathrm{CO}_{2}$ production levels. Coal char might be an attractive catalyst for tar reduction in the gasification process because of its effective activity and economic advantage. In addition, the interaction between coal char and biomass derived tar is expected to be a useful consideration in the design and operation of coal and biomass processing plants.

Acknowledgements: The authors appreciate the financial support from Royal Golden Jubilee PhD. Program, Thailand Research Fund (code No. PhD/0150/2551) and the Fuels Research Centre, Department of Chemical Technology, Chulalongkorn University.

\section{REFERENCES}

1. Jun H, Heejoon K (2008) The reduction and control technology of tar during biomass gasification/pyrolysis: An overview. Renew Sustain Energ Rev 12, 397-416.

2. Anis S, Zainal ZA (2011) Tar reduction in biomass producer gas via mechanical, catalytic and thermal methods: A review. Renew Sustain Energ Rev 15, 2355-77.

3. Sun Q, Yu S, Wang F, Wang J (2011) Decomposition and gasification of pyrolysis volatiles from pine wood through a bed of hot char. Fuel 90, 1041-8.

4. Zhang L, Matsuhara T, Kudo S, Hayashi J, Norinaga K (2013) Rapid pyrolysis of brown coal in a drop-tube reactor with co-feeding of char as a promoter of in situ tar reforming. Fuel 112, 681-6.

5. Abu El-Rub Z, Bramer EA, Brem G (2008) Experimental comparison of biomass chars with other catalysts for tar reduction. Fuel 87, 2243-52.

6. Gilbert P, Ryu C, Sharifi V, Swithenbank J (2009) Tar reduction in pyrolysis vapours from biomass over a hot char bed. Bioresour Tech 100, 6045-51.

7. Brandt P, Larsen E, Henriksen U (2000) High tar reduction in a two-stage gasifier. Energ Fuel 14, 816-9.

8. Min Z, Yimsiri P, Asadullah M, Zhang S, Li CZ (2011) Catalytic reforming of tar during gasification. Part II. Char as a catalyst or as a catalyst support for tar reforming. Fuel 90, 2545-52.

9. Krerkkaiwan S, Fushimi C, Tsutsumi A, Kuchonthara P (2013) Synergetic effect during co-pyrolysis/gasification of biomass and sub-bituminous coal. Fuel Process Tech 115, 11-8.

10. Park DK, Kim SD, Lee SH, Lee JG (2010) Copyrolysis characteristics of sawdust and coal blend in TGA and a fixed bed reactor. Bioresour Tech 101, 6151-6.

11. Sonobe T, Worasuwannarak N, Pipatmanomai S (2008) Synergies in co-pyrolysis of Thai lignite and corncob. Fuel Process Tech 89, 1371-8.

12. López D, Acelas N, Mondragón F (2010) Average structural analysis of tar obtained from pyrolysis of wood. Bioresour Tech 101, 2458-65.

13. Xiao R, Yang W (2013) Influence of temperature on organic structure of biomass pyrolysis products. Renew Energ 50, 136-41.

14. Zhang D (2009) Thermal decomposition of coal. In: Jinsheng G (ed) Coal, Oil Shale, Natural Bitumen, 
Heavy Oil, and Peat, Vol. 1. Encyclopedia of Life Support Systems, Eolss Publishers, Oxford. pp 340-59.

15. Singla PK, Miura S, Hudgins RR, Silveston PL (1983) Pore development during carbonization of coals. Fuel 62, 645-8.

16. Wang J, Du J, Chang L, Xie K (2010) Study on the structure and pyrolysis characteristics of Chinese western coals. Fuel Process Tech 91, 430-3.

17. Onay $\mathrm{O}$ (2007) Influence of pyrolysis temperature and heating rate on the production of bio-oil and char from safflower seed by pyrolysis, using a well-swept fixedbed reactor. Fuel Process Tech 88, 523-31.

18. Zanzi R, Sjöström K, Björnbom E (1996) Rapid hightemperature pyrolysis of biomass in a free-fall reactor. Fuel 75, 545-50.

19. Lu L, Kong C, Sahajwalla V, Harris D (2002) Char structural ordering during pyrolysis and combustion and its influence on char reactivity. Fuel 81, 1215-25.

20. Masek O, Sonoyama N, Ohtsubo E, Hosokai S, Li CZ, Chiba THayashi J (2007) Examination of catalytic roles of inherent metallic species in steam reforming of nascent volatiles from the rapid pyrolysis of a brown coal. Fuel Process Tech 88, 179-85.

21. Hayashi JI, Iwatsuki M, Morishita K, Tsutsumi A, Li CZ, Chiba T (2002) Roles of inherent metallic species in secondary reactions of tar and char during rapid pyrolysis of brown coals in a drop-tube reactor. Fuel 81, 1977-87.

22. Hosokai S, Norinaga K, Kimura T, Nakano M, Li CZ, Hayashi JI (2011) Reforming of Volatiles from the Biomass Pyrolysis over Charcoal in a Sequence of Coke Deposition and Steam Gasification of Coke. Energ Fuel 25, 5387-93.

23. Worasuwannarak N, Sonobe T, Tanthapanichakoon W (2007) Pyrolysis behaviors of rice straw, rice husk, and corncob by TG-MS technique. J Anal Appl Pyrol 78, 265-71.

24. Tsai WT, Lee MK, Chang YM (2006) Fast pyrolysis of rice straw, sugarcane bagasse and coconut shell in an induction-heating reactor. J Anal Appl Pyrol 76, 230-7.

25. Hashimoto K, Miura K, Xu J-J, Watanabe A, Masukami H (1986) Relation between the gasification rate of carbons supporting alkali metal salts and the amount of oxygen trapped by the metal. Fuel 65, 489-94.

26. Wigmans T, Elfring R, Moulijn JA (1983) On the mechanism of the potassium carbonate catalysed gasification of activated carbon: the influence of the catalyst concentration on the reactivity and selectivity at low steam pressures. Carbon 21, 1-12.

27. Mims CA, Pabst JK (1983) Role of surface salt complexes in alkali-catalysed carbon gasification. Fuel 62, 176-9.

28. Okuno T, Sonoyama N, Hayashi J, Li CZ, Sathe CChiba T (2005) Primary release of alkali and alkaline earth metallic species during the pyrolysis of pulverized biomass. Energ Fuel 19, 2164-71.

29. Wang J, Jiang M, Yao Y, Zhang Y, Cao J (2009)
Steam gasification of coal char catalyzed by $\mathrm{K} 2 \mathrm{CO} 3$ for enhanced production of hydrogen without formation of methane. Fuel 88, 1572-9.

30. Wu Y, Wang J, Wu S, Huang S, Gao J (2011) Potassium-catalyzed steam gasification of petroleum coke for $\mathrm{H}_{2}$ production: Reactivity, selectivity and gas release. Fuel Process Tech 92, 523-30.

31. Wood BJ, Fleming RH, Wise H (1984) Reactive intermediate in the alkali-carbonate-catalysed gasification of coal char. Fuel 63, 1600-3.

32. Yang H, Yan R, Chen H, Lee DH, Zheng C (2007) Characteristics of hemicellulose, cellulose and lignin pyrolysis. Fuel 86, 1781-8.

33. Fu P, Yi W, Bai X, Li Z, Hu S, Xiang J (2011) Effect of temperature on gas composition and char structural features of pyrolyzed agricultural residues. Bioresour Tech 102, 8211-9.

34. Shi L, Yu S, Wang FC, Wang J (2012) Pyrolytic characteristics of rice straw and its constituents catalyzed by internal alkali and alkali earth metals. Fuel 96, 586-94.

35. Hosokai S, Kumabe K, Ohshita M, Norinaga K, Li CZ, Hayashi JI (2008) Mechanism of decomposition of aromatics over charcoal and necessary condition for maintaining its activity. Fuel 87, 2914-22.

36. Min ZH, Asadullah M, Yimsiri P, Zhang S, Wu HW, Li CZ (2011) Catalytic reforming of tar during gasification. Part I. Steam reforming of biomass tar using ilmenite as a catalyst. Fuel 90, 1847-54.

37. Demicheli MC, Duprez D, Barbier J, Ferretti OA, Ponzi EN (1994) Deactivation of Steam-Reforming Model Catalysts by Coke Formation. II. Promotion with Potassium and Effect of Water. J Catal. 145, 437-49. 